\title{
THE VALUE OF GRASS IN REDUCING FARM WINTERING COSTS IN HAWKE'S BAY
}

\author{
I. B. SPIERS \\ Farmer, Takapau
}

\begin{abstract}
Historical data on stocking rates and supplementary feed used on the 321 ha farm are given for the years 1970 to 1975 . During this period major changes in winter grazing management practices were adopted. Management changes and reasons for them are described and cost of and labour advantages of these changes; associated with a reduction of supplementary feed, are outlined: It is concluded that increases in stocking rates do not necessarily increase profit since in some instances they cause an increase in supplementary feeding. It is also concluded that the -farm could, winter- 18 " stock units/ha provided buying and selling policies were correctly timed and management systems used that can control intakes to the level desired.
\end{abstract}

\section{INTRODUCTION}

I FARM 321 ha of flat country at Takapau subdivided into 32 paddocks. Soil types are Matamau, Kopua, and Roumati silt loams. Much of the wetter country has been tiletdrained but there are still a number of wet paddocks.

About 60 ha are cropped each year for grain. In the past choumoellier was grown foe winter feed but now each paddock is cropped twice for barley and green feed grown between grain crops. New pastures consist of perennial ryegrass, cocksfoot, white and subterranean clover; 2.5 tonnes of lime and $375 \mathrm{~kg}$ of superphosphate are applied with pasture. A further $250 \mathrm{~kg}$ of superphosphate are applied the following spring and maintenance applications are $250 \mathrm{~kg}$, with 2.5 tonnes of lime each 5th year. There are 39 ha in lucerne, 17 ha of which is for processing and 10 ha overdrilled with prairie grass for grazing.

Stacking rates have varied from 14.4 to 17.2 stock units/ha. This winter, the stocking rate is 16.2 stock units/ha.

Half the ewes are Romneys mated to Border Leicesters. Firstcross ewes are mated to the Hampshire Down, In the past roughly half the cattle were heifers for the spring vealer market 'and the other half steers' and Friesian bulls. Over the last two years my veal market has gone and I now raise bulls of varying ages and 
some steers. I run 400 to 450 cattle through the winter and buy in 100 to 150 more in July/August. This suits my farming system and equates well with seasonal grass growth patterns.

This paper describes the farming system used for wintering stock - the reasons for it and the value of. winter grassland management.

\section{BACKGROUND}

\section{SHEEP}

Under my old sheep wintering system, I shut up ewes in two mobs on 50 ha from May until lambing. The Border Leicesters were fed $500 \mathrm{~g}$ of hay plus barley (rising from $55 \mathrm{~g} / \mathrm{day}$ to $170 \mathrm{~g}$ ). The Romneys were fed 750 to $1000 \mathrm{~g}$ of lucerne hay/ day.

This system had some disadvantages.

(1) It was costly and costs were increasing.

(2) It involved a lot of time.

(3) At lambing there were 50 ha which did not grow much grass till late spring. With 30 ha in lucerne and 25 ha in winter crop this meant space at lambing time became critical.

\section{CAtThe}

Steers and bulls were fed grass and hay until mid-July, when the steers were put into a feed lot, and bulls were fed on a crop of choumoellier. Top priority heifers for the spring butchers' market were fed grass throughout the winter.

Table 1 shows the stock tallies over the last six years and supplementary feed fed.

In 1970 the steers to be fattened in summer were confined in a feed lot. This gave more scope for fattening cattle for the spring butchers' market. In 1971, both sheep and cattle numbers were increased and the amount of supplementary feed rose dramatically. In 1972 , I cut down stock numbers but was still feeding 4250 bales of hay to cattle, of which 120 steers in the feed lot were eating 2300 bales.

On the basis of a nitrogen trial in 1972, I decided to feed less hay and use more nitrogen. In 1972 urea cost $\$ 70 /$ tonne or approximately $\$ 7.40 /$ ha and per kilogram of dry matter was cheaper. 
TABLE 1: STOCK NUMBERS AND SUPPLEMENTARY FEED USED, $1970-5$

\begin{tabular}{|c|c|c|c|c|c|c|}
\hline & 1970 & 1971 & 1972 & 1973 & 1974 & 1975 \\
\hline \multicolumn{7}{|l|}{ Stock numbers (winter) } \\
\hline Sheep - Ewes & 2598 & 3090 & 2673 & 2760 & 2665 & 2530 \\
\hline - Hoggets & 552 & 513 & 520 & 550 & 704 & 675 \\
\hline Cattle - June & 448 & 494 & 460 & 458 & 233 & 441 \\
\hline - July & 448 & 494 & 487 & 555 & 503 & 441 \\
\hline $\begin{array}{c}\text { Total stock units } \\
- \text { July }\end{array}$ & 4638 & 5417 & 4970 & 5511 & 5417 & 5245 \\
\hline \multicolumn{7}{|l|}{ Hay fed (bales): } \\
\hline Sheep & 2400 & 3650 & 3300 & 3877 & & \\
\hline Cattle & 5000 & 5650 & 4250 & 3030 & 2000 & 5600 \\
\hline Total & 7400 & 9300 & 7550 & 6907 & 2000 & 5600 \\
\hline \multicolumn{7}{|l|}{ Barley fed (tonnes) : } \\
\hline Sheep & 5.5 & 8.0 & 5.0 & & & \\
\hline
\end{tabular}

In 1973 no cattle were put into the feed lot. Steers and bulls were strip-grazed with daily breaks, and fattening heifers were block-grazed with shifts every four or five days on nitrogenboosted pastures. This was successful with only 3000 bales fed to 555 cattle. In 1974 similar methods were used and hay fell to 2000 bales. Up to 1972,450 to 500 cattle were bought in the autumn, but in 1973 and 1974 fewer cattle were wintered. I decided to build up feed in the autumn and refrain from buying stock for summer fattening until late winter. This suits my grass growth pattern and the class of stock carried. Obviously the earlier cattle can be bought in spring the cheaper they will be and I would buy early in July provided I had on hand enough cattle grass for three weeks to a month. I would then expect to feed hay for only a short period over lambing when ewes and lambs have top priority.

This year cattle were cheap in autumn and, with the prospect of the 55 cent October Schedule, I replaced early and bought heavier cattle than I normally do. With an expected sharp rise in the store price, the nearer we got to October this seemed the only way to show a profit. However, total 'stock units winter fed rose by 1100 and the cattle ate 5600 bales of hay. Given a normal schedule price year, I would winter fewer cattle and buy in late winter/early spring. The effect of changes in stock numbers and time of purchase and supplementary feed costs can be seen in Table 2. These are actual costs which are lower than opportunity costs. 
TABLE 2: COSTS OF SUPPLEMENTARY FODDERS

\begin{tabular}{ccccccc}
\hline & $\mathbf{1 9 7 0}$ & $\mathbf{1 9 7 1}$ & $\mathbf{1 9 7 2}$ & $\mathbf{1 9 7 3}$ & $\mathbf{1 9 7 4}$ & $\mathbf{1 9 7 5}$ \\
\hline Hay and barley & & & & & & \\
$\quad \begin{array}{l}\text { Feed costs: } \\
\text { Sheep (\$/stock unit) }\end{array}$ & 0.47 & 0.70 & 0.74 & 1.46 & nil & nil \\
$\begin{array}{l}\text { Cattle (\$/stock unit) } \\
\text { Total costs/stock unit }\end{array}$ & 1.27 & 1.38 & 1.14 & 1.33 & 0.29 & 0.83 \\
$\quad \begin{array}{l}\text { including fodder crops } \\
\text { and nitrogen application }\end{array}$ & 1.12 & 1.52 & 1.30 & 2.06 & 0.75 & 0.63 \\
\hline
\end{tabular}

In 1973 hay was down but a severe drought caused a rise in costs and some hay had to be bought in from outside Hawke's Bay, increasing the average cost to $\$ 1.04 / \mathrm{bale}$.

In 1974 no hay was made and the lucerne that would have produced hay was sold, netting $\$ 4500$, which in effect made the wintering cost per stock unit zero.

\section{RESULTS OF MANAGEMENT AND FEEDING SYSTEMS}

CATTLE

(a) Results (1970-72) from Steers in the Feed Lot

One hundred and twenty steers weighing $250 \mathrm{~kg}$ were fed $5 \mathrm{~kg}$ hay/day for 90 days. Daily liveweight gain averaged $0.25 \mathrm{~kg}$. Total liveweight gain was $20.5 \mathrm{~kg}$, or approximately $10 \mathrm{~kg}$ carcass weight. At $68 \mathrm{c} / \mathrm{kg}$ (1972 schedule), this meant the carcass weight gain was worth $\$ 6.80$. Over 90 days 1 fed 20 bales of hay per head, which meant that the break-even cost of hay was 34c per bale. In 1972 the profitability of hay feeding was doubtful, but today it is just not on.

\section{(b) Results from N-boosted Grass}

In June 1972, weaner heifers were stocked at 4.8/ha and 7.2/ ha on pasture which had been topdressed with $112 \mathrm{~kg} / \mathrm{ha}$ of urea to determine an optimum stocking rate. At 7.2 / ha hay had to be fed but results showed I could run $160 \mathrm{~kg}$ vealers at $6.2 /$ ha for a 0.75 gain/day and expect to kill them in September at a liveweight of $227 \mathrm{~kg}$.

In 1973 I weighed bulls through the winter and spring. These $350 \mathrm{~kg}$ cattle were strip grazed on 13 ha topdressed with $112 \mathrm{~kg} /$ ha urea from May to July with a daily shift. Daily gain was $0.9 \mathrm{~kg}$. They were then fed choumoellier for 63 days and lost 
$2.7 \mathrm{~kg}$. In October the mob was block-grazed on 13.4 ha su.bdivided into six blocks, this area being topdressed with $124 \mathrm{~kg} / \mathrm{ha}$ urea on September 1 and had about $4000 \mathrm{~kg} \mathrm{DM} / \mathrm{ha}$ at the start of the rotation. Pasture utilization averaged approximately $60 \%$. The bulls averaged $408 \mathrm{~kg}$ on October 5. During the first 26 . day rotation, liveweight gain was $2.1 \mathrm{~kg} / \mathrm{day}$. Weights were not recorded on the second rotation but good liveweight gains during winter and spring meant that killing started in mid-December, and by January $185 \%$ had gone at an average carcass weight of $285 \mathrm{~kg}$. This gave flexibility in handling a large number of cattle.

Choumoellier was proved to be unreliable for weight gains and I decided fodder radish could provide a bulk of feed for cattle over lambing and could be grown after a grain crop.

\section{SHEEP}

After success in reducing cattle supplementary feeding, I decided to apply similar principles to sheep. I purchased $740 \mathrm{~m}$ of electrified netting to control sheep and wintered 2600 ewes in a 116 ha rotation. Some of the 116 ha was grazed by cattle, and carrying capacity was in excess cvf 23 stock units/ha over winter, which compares favourably with the whole farm winter stocking rate of just under 17 .

lnitialiy the decision was made to shift ewes every two days, starting at the end of tupping. The area required for two days' grazing was calculated using feed budgeting principles. Grass present was estimated visually and it was assumed that sheep at maintenance would eat down to $400 \mathrm{~kg} \mathrm{DM} / \mathrm{ha}$. Some pasture cuts were taken to check the accuracy of estimations. Feed requirements were 0.8 maintenance until mid-July and maintenance from then until just before lambing. Sample liveweights of ewes throughout winter showed that the liveweight changes expected from these feeding levels were achieved.

The management system worked well in spite of 1974 being an extremely wet year and the main points arising were:

(1) For optimum pasture ragrowth, shifts every two days gave excellent results.

(2) During wet weather grazing pressure was doubled and ewes moved daily. This reduced pugging end improved pasture utilization.

(3) As the rotation progressed, the need to feed budget diminished. It is important to recognize the residual $400 \mathrm{~kg} \mathrm{DM} / \mathrm{ha}$ and time shifts accordingly. 
(4) An ordered rotation is necessary. On this farm it is better to utilize the wet country first. Jobs such as crutching need to be arranged when sheep are near the yards. Sheep should not be driven, but rather should flow into adjacent paddocks.

(5) Animal health is important. Worm-free ewes at the start means low worm re-infestation, so I think it is a good idea to drench ewes, especially two-tooths, before the start of the rotation. I have had a problem over the last four years with vibriosis. To try to reduce the spread of the disease last year I moved the ewes daily once aborted lambs appeased. This did not work and the two-tooths were spread out about three weeks before lambing. This year I delayed malting them and at the time of writing only oae ewe had aborted. The only other health problem encountered was mud going hard between the toes after wet weather.

(6) Perhaps the most important point is that of coat saving. Ewes are eating a calculated ration of grass. It is also labour saving. Approximately two to three hours per week were spent setting up a week's grazing and moving of ewes each second day takes only a few minutes.

I would also point out that the electric netting has been a very worthwhile aid in my situation. It is light to carry, quick to erect, and allows for greater flexibility in wet weather. However, it is not essential to the system and there are many hill country farmers in Hawke's Bay wintering large mobs of sheep in the same way without electric netting.

\section{CONCLUSIONS}

On the basis of the physical and financial records I have kept over the years, I have the following conclusions:

(1) Increasing stocking rate does not necessarily increase net income since it has a sizeable effect on supplementary feed costs.

(2) A farming system that does away with supplementary feeding is likely to become more pro\&able.

(3) This farm grows enough feed to winter 5500 stock units or about 18 stock units/ha without supplementary feed. Spring and summer carrying capacity is much higher than this, therefore the winter carrying capacity is the limiting factor. 
(4) To carry 18 stock units/ha without supplementary feed I need to use a farming system that accurately rations feed during the winter. I need to determine stock priorities and to buy and sell cattle at the time best suited to my pasture growth curve. It is better to build up feed in the autumn, which will allow me to achieve high winter growth rates without the use of supplementary feed or nitrogen-boosted grass.

(5) The break- or block-grazing system for both sheep and cattle gives me the ability to control feed- to livestock.

(6) In future I would hope to mob-stock ewes earlier, but under lesser grazing pressure in an effort to help build up autumn feed.

(7) The cost of supplementary feed of any kind, whether it is hay, barley, fodder crops, or nitrogen-boosted grass, is extremely high and any manipulation of feeding systems and buying and selling policies that fits feed demand to the feed supplied by grass must have a profound effect on net income.

And finally, quite apart from costs, I personally have no desire to spend half the summer making 10000 bales of bay. In winter, to feed 80 bales of hay per day is hard work and to me becomes a daily chore. Labour is a valuable asset on the farm today, and many man-hours are involved. My aim is to have my hay berns full as an insurance against drought or severe winter, but to feed out as little as possible.

The erecting and pulling down of fences can be done at one's convenience, and involves little work and the movement of stock is a pleasure. It is not necessary to go out in a howling southerly to feed out.

I believe I can farm at a relatively high stocking rate and use little or no supplementary feed provided my grass feeding programme is planned and controlled. 